\title{
MECHANISMS FOR THE DEVELOPMENT OF THE AGRICULTURAL SECTOR IN THE ECONOMIC SECURITY OF THE STATE
}

\author{
aOksana V. Pronina*, bIryna P. Dynnyk, bIryna V. Lazebna, cLina M. Shchurevych, dOlena M. Krapko \\ aKherson National Technical University, Kherson, Ukraine. \\ ${ }^{b}$ Kyiv National University of Trade and Economics, Kyiv, Ukraine. \\ 'Kyiv Regional State Administration, Kyiv, Ukraine. \\ ${ }^{d}$ National Aviation University, Kyiv, Ukraine.
}

\section{ART ICLE INFO}

\section{Article History}

Received: April 21, 2021

Revised: July 1, 2021

Accepted: July 30, 2021

\section{Keywords}

Agrarian policy

Investment

Innovation

Destabilizing factors

National interests

\section{A B S T R A C T}

The article explored the problems of formation and improvement of mechanisms to ensure the development of the agricultural sector in the state's economic security system. It has been found that today socio-economic transformations actualize the urgent need to improve scientific and methodological research and development on the creation and implementation of an effective state agrarian policy, as well as the development of innovative management decisions to ensure and accelerate the development of the agricultural sector to strengthen the general economic security system of Ukraine. Approaches to the definition of the category "economic security of the state" were summarized and a refined definition was provided. A universal and effective mechanism for ensuring the development of the agricultural sector in the system of economic security of the state has been developed, the functioning of which, in turn, is directly dependent on internal and external destabilizing factors and will be based on the improvement of three interconnected mechanisms: strengthening the food security of the state; increasing investment attractiveness by introducing an innovative component; optimization of agricultural sector financial support. The differences and interrelationships of the types of destabilizing factors affecting the economic security of the agricultural sector were analyzed and it was concluded that all these factors can both negatively affect the entire economic security system in the agricultural sector and be areas of constant improvement. Block proposals for strengthening the food security of the state are described. It has been proved that to be able to develop and implement these innovative methods requires significant investment injections from both the state and Ukrainian investors, as well as external investments on favorable conditions for agricultural sector entities. Proposals on optimization of financial support of the agricultural sector in the changing conditions of the present are presented.

Corresponding Author: Oksana V. Pronina

Email: ovpronina-7298-2@kpi.com.de

(c) The Author(s) 2021.

\section{INTRODUCTION}

Today, the agrarian sector of the Ukrainian economy tends to be constantly dynamic, implementing a great influence in the overall performance of the national economy. This impact is particularly evident in meeting the food needs of members of civil society, providing small, medium and industrial enterprises with a number of processing industries with raw materials, building 
sustainable export capacity, and creating a basis for the food security of the state in the changing conditions of present time. But it should be noted that despite the positive trends identified, the socio-economic development of the agricultural sector is not sufficiently realized in modern economic conditions, which leads to a significant decrease in the overall indicators of economic security of the state (financial, production, international economic, social, food, etc.). The implementation of mechanisms for the development of the agricultural sector as a basis for its sustainable functioning and ensuring the economic security of the national economy creates the need for the introduction of effective tools that could increase the productivity of the use of resource and technological potential in agriculture, improving the overall sectoral structure with the possibility of introducing the production of a completed food cycle.

This will allow the state to reduce dependence on imports of strategically important food products, increase the socio-economic efficiency of enterprises associated with the agricultural sector in one way or another, with the ability to take into account their contribution to the development of agricultural territories. So, to date, socio-economic transformations actualize the urgent need to improve scientific and methodological research and development on the construction and implementation of an effective state agrarian policy, as well as the development of innovative management decisions to ensure and accelerate the development of the agricultural sector to strengthen the general economic security system of Ukraine.

A large number of scientific works of well-known scientists are devoted to the study of theoretical, methodological, and practically applied bases for ensuring the development of the agricultural sector of the economy and its influence on the reliability of the general system of economic security of the state, such as Avanesova et al. (2020), Boiko (2017), Romanenko (2016), Lelechenko et al. (2020), Orlova et al. (2019), Nepomnyashchyy et al. (2020), Shevchenko et al. (2020), Gevorgyan et al. (2018), Kruhlov and Tereshchenko (2019), Hryhorenko (2017); Urba (2017, 2019); Zinchuk (2017), Bianco (2016); Brockwell and Davis (2016); Hunchak et al. (2016); Popova (2016); Riabokon (2016) (2016), Honcharenko (2017) and Stetsiuk (2016).

\section{MATERIALS AND METHODS}

By summarizing and analyzing the work of these scientists, it can be concluded that they have elaborated a large number of aspects of this issue and made substantive conclusions. But it should be noted that some mechanisms remained insufficiently studied, which are the key basis for the effective development of the agricultural sector in the state's economic security system. The purpose of the article is the formation and practical application of mechanisms to ensure the development of the agricultural sector in the state's economic security system. To achieve the purpose, the tasks are as follows:

-to clarify the category of "economic security of the state";

-to build a common mechanism to ensure the development of the agricultural sector in the state's economic security system;

-to analyze the differences and interrelationships between the types of destabilizing factors affecting the economic security of the agricultural sector;

-to provide practical advice on improving selected mechanisms for the development of the agricultural sector.

According to the trends of the present, an effective system of economic security of the country under both global and internal challenges becomes a determining factor in ensuring the ability to realize national interests in Ukrainian and world policies, the ability of the state to overcome the economic crisis with possible external aggression. That is why research and synthesis of modern approaches to determining the essence of economic security becomes especially relevant, given the constant socio-economic transformation in the agricultural sector.

So, in Figure 1, by summarizing approaches to the definition of the concept of "economic security of the state", the essence of this category taking into account the peculiarities of the development of the agricultural sector of the economy of Ukraine will be clarified.

As can be seen from the definition of the "economic security of the state" category, presented in Figure 1, the key aspect is the improvement of mechanisms for the functioning of strategically important sectors of the economy, which is, in particular, the agricultural sector studied in the article. Note that in the general sense, the essence of the concept of "agricultural sector of the economy" lies in the relationship of its four components, 
namely:

1) a combination of different agricultural and processing industries, which are in constant integrated communication with each other and with the external environment.
2) is a key component of the national economy.

3) acts as the central link of the agro-industrial complex.

4) a combination of enterprises of different forms of management ((Nepomnyashchyy et al., 2020).

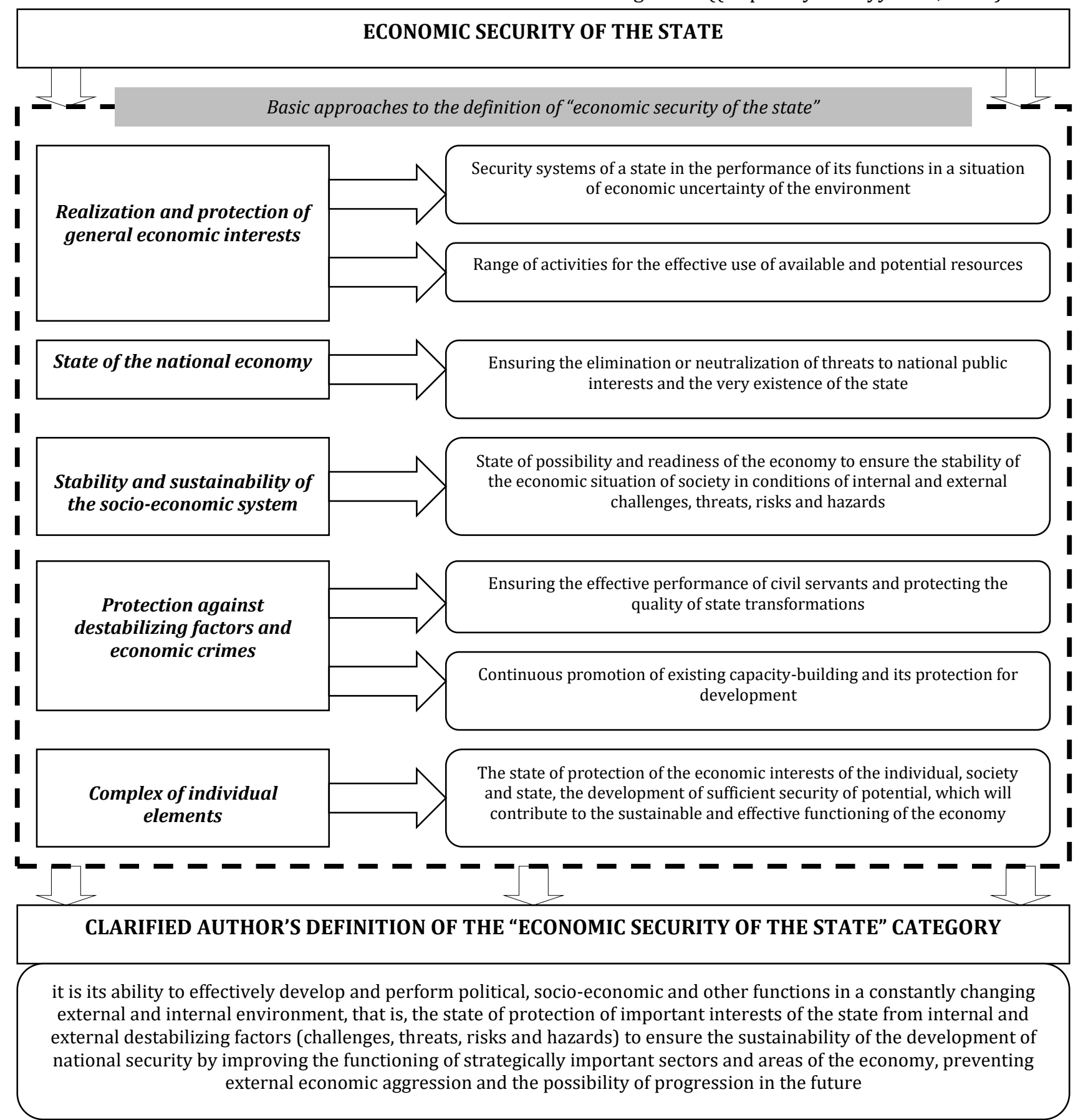

Figure 1. Clarification of the "economic security of the state" category.

Source: generalized on the basis of Avanesova et al. (2020); Boiko (2017); Lelechenko et al. (2020); Nepomnyashchyy et al. (2020); Orlova et al. (2019); Romanenko (2016).

So, it can be concluded that the agricultural sector can both form the resource basis of the socio-economic 
development of the state while ensuring its food security, and create the prerequisites for the development of the agro-industrial complex by increasing economic efficiency and export potential, as well as creating reliable security for the development of agricultural territories for various purposes with available or potential possible infrastructure. Therefore, the main practical task of this study is to create a common mechanism for ensuring the development of the agricultural sector in the system of economic security of the state, the functioning of which, in turn, directly depends on internal and external destabilizing factors and will be based on the improvement of three interconnected mechanisms, namely:

I. Strengthening the food security of the state.

II. Increasing investment attractiveness by introducing an innovative component.

III. Optimization of agricultural sector financial support.

\section{RESULTS AND DISCUSSION}

As can be seen from Figure 1, the mechanism is centered on destabilizing factors that affect both the functioning of subjects, principles, and institutional and legal support, and is the driving force behind the identification of individual mechanisms within the common body with a view to improving them in the future. By summarizing scientific sources (Avanesova et al., 2020; Orlova et al., 2019; Romanenko, 2016; Urba, 2019; Zinchuk, 2017) the following definition of the "destabilizing factor" category can be provided - a combination of existing and/or potential challenges, threats, risks, and hazards that directly or indirectly affect all aspects of social and economic development, the effective realization of national interests, as well as the provision of economic security in general. It should be noted that in the agrarian sphere, destabilizing factors are especially considerable compared to other sectors of the economy.

This is due to the variability of the external and internal environment in which the agro-industrial complex of Ukraine is constantly operating and expressed in the following manifestations:

- continuous changes in legislation and business conditions;

- lack and outflow of skilled (often almost all) personnel from rural areas;

- significant technical and material deterioration of fixed assets and intangible assets;

- increased competition for integration into the European Union and other international markets;

- dependence on public funding;

- abnormal weather conditions recently observed in Ukraine;

- difficulties in prediction of fluctuations in prices of basic agricultural products, etc.

Thus, on the basis of the above in Table 1, it is possible to study the differences and interrelationships of the four types of destabilizing factors of economic security with respect to the agricultural sector of the economy.

Table 1. Differences and interrelationships between types of destabilizing factors.

\begin{tabular}{|c|c|c|c|}
\hline No. & $\begin{array}{l}\text { Destabilizing } \\
\text { factor }\end{array}$ & General characteristic & $\begin{array}{l}\text { Examples regarding the } \\
\text { agricultural sector of the economy }\end{array}$ \\
\hline \multicolumn{4}{|c|}{ I. Level. Potential manifestations and phenomena } \\
\hline 1.1 & Challenges & $\begin{array}{l}\text { a combination of both positive and negative influences } \\
\text { to which an adequate response should be made, } \\
\text { because ignoring them can lead to unpredictable } \\
\text { possible destructive consequences, which will lead to a } \\
\text { decrease in the overall security of the agricultural } \\
\text { sector }\end{array}$ & $\begin{array}{l}\text { Integration into the international } \\
\text { markets of the European Union } \\
\text { and vice versa competing with } \\
\text { external producers in Ukraine's } \\
\text { agricultural market; introduction } \\
\text { of the innovation component; } \\
\text { internal competition, etc. }\end{array}$ \\
\hline \multicolumn{4}{|c|}{ II. Level. Real manifestations and phenomena } \\
\hline 2.1 & Threats & $\begin{array}{l}\text { is defined as the influence of entities or internal } \\
\text { elements of the system of internal and/or external } \\
\text { environment, which can actually lead to economic } \\
\text { losses and reduce the overall security of the agricultural } \\
\text { sector }\end{array}$ & $\begin{array}{l}\text { Shortage of personnel due to } \\
\text { personnel outflows, complete } \\
\text { depreciation of fixed assets and } \\
\text { intangible assets, production of } \\
\text { non-competitive products due to } \\
\text { outdated equipment, etc. } \\
\text { Investment risks credit risks, }\end{array}$ \\
\hline 2.2 & Risks & this is the occurrence of expected or unpredictable & Investment risks, credit risks, \\
\hline
\end{tabular}


events in different areas of the agricultural sector due to the actualization of challenges and threats that can lead to differential effects (positive or negative), as well as deviations from the desired economic indicators insurance risks, production risks, etc.

\begin{tabular}{lll} 
III. Level. Destructive manifestations and phenomena & \\
\hline Dangers & $\begin{array}{l}\text { This is a form of challenges, threats, and risks leading to } \\
\text { real economic losses and other negative consequences and large contracts }\end{array}$ & $\begin{array}{l}\text { Loss of mith processing enterprises of the } \\
\text { agricultural sector, inability to } \\
\text { carry out further activities, etc. }\end{array}$
\end{tabular}

Source: author's development based on (Hunchak et al., 2016; Popova, 2016; Urba, 2017; Avanesova et al., 2020).

All of these factors shown in Table 1 can both negatively affect the entire economic security system in the agricultural sector and be areas of constant improvement. As can be seen from Figure 2, this study identifies three fundamental directions for improving the mechanism for ensuring the agricultural sector in the state's economic security system. Therefore, their comprehensive study and practical recommendations for improving individual mechanisms will increase the practical value of the article.

I. Strengthening the food security of the state. In general terms, food security is a state of social and economic development of the state, in which all members of the community have sufficient food and quality and, of course, assortment, which provides an opportunity to support a high level of their physical and psychological health. As can be seen from Figure 2, five interrelated units can be identified among the mechanisms for enhancing food security, namely, adherence to certain principles of food security; interconnectedness of agricultural sector development components; production of an improved model of food availability; measures to increase the economic availability of food to end-users; improving quality and ensuring safety of agricultural products. In Figure 3, a detailed description of each block as an important unit will be provided for creating a reliable system of food security of the state. Thus, the implementation of the measures proposed in Figure 3 should be reinforced by comprehensive information and analytical support, which, on the one hand, will be used to monitor and control the implementation of these events, and on the other, provide for an improvement in the image of Ukrainian producers of the agricultural sector, which together will ensure the formation of a resource base for ensuring reliable and stable food security of the state.
II. Increasing investment attractiveness by introducing an innovative component. This area of improvement is directly related to the continuous development of scientific and technological progress and the constant introduction of its achievements in all sectors of management (production, management, sales, etc.). Without the use of modern innovative methods, the agricultural sector will not be able to win the competition of world agricultural markets. But today, in order to be able to develop and implement these innovative methods, significant investment injections are required from both the state and Ukrainian investors, as well as external investments on conditions favorable for agricultural sector entities. Thus, through the generalizations of scientific sources (Honcharenko, 2017; Hunchak et al., 2016; Shevchenko et al., 2020; Urba, 2019) five proposals were formed to improve the mechanism of functioning of the investment and innovation component of the agricultural sector.

1. The intensification of scientific, technical, and project activities in the agricultural sector of the economy consists in the constant development, scientific and financial, and economic justification of possible innovations with their active introduction into practice to reduce the lag of the agricultural sector of Ukraine from world leaders in this sector of the economy.

2. Development and implementation of investment and innovation projects - is carried out by approving the strategic and operational plan for obtaining investments and directing them to cost-effective areas to achieve the desired effect.

3. The growth of opportunities in the intellectual and personnel support of the agricultural sector-the implementation of investment and innovation projects requires highly qualified specialists in various fields of science. 


\section{GENERAL MECHANISM FOR THE DEVELOPMENT OF THE AGRICULTURAL}

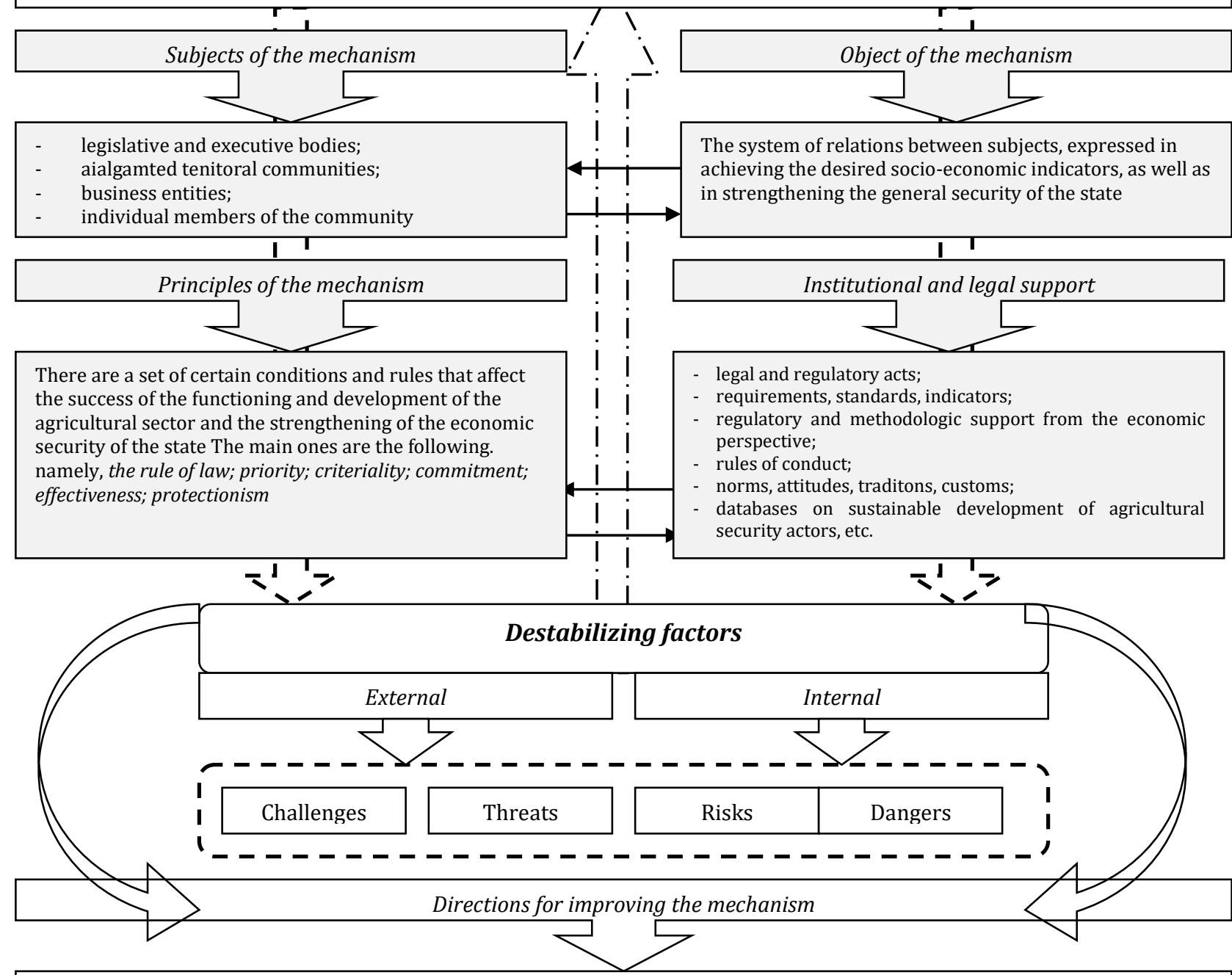

1.1 Following certain principles of food security.

1.2 Interconnection of agricultural sector development components.

1.3 Implementation of an improved model of food availability.

1.4 Measures to increase the economic availability of food to end consumers.

1.5 Improving the quality and safety of agricultural products.

II. Increasing investment attractiveness by introducing an innovative component

2.1 Intensification of scientific, technical and project activities in the agricultural sector of the economy

2.2 Development and implementation of investment and innovative projects

2.3 Growth of opportunities in the intellectual and personnel support of the agricultural sector.

2.4 Modernization of the agro-industrial complex.

2.5 Strengthening the competitive position of the agricultural sector of Ukraine to attract external investments.

3.1 State support for agricultural production.

\section{Optimization of agricultural sector financial support}

3.2. Commercial lending.

3.3 Investment support.

3.4 Development of cooperative banks system.

3.5 Alternative sources.

Figure 2. The general mechanism for ensuring the development of the agricultural sector in the state's economic security system.

Source: author's development based on (Kruhlov and Tereshchenko, 2019; Shevchenko et al., 2020; Zinchuk, 2017). 


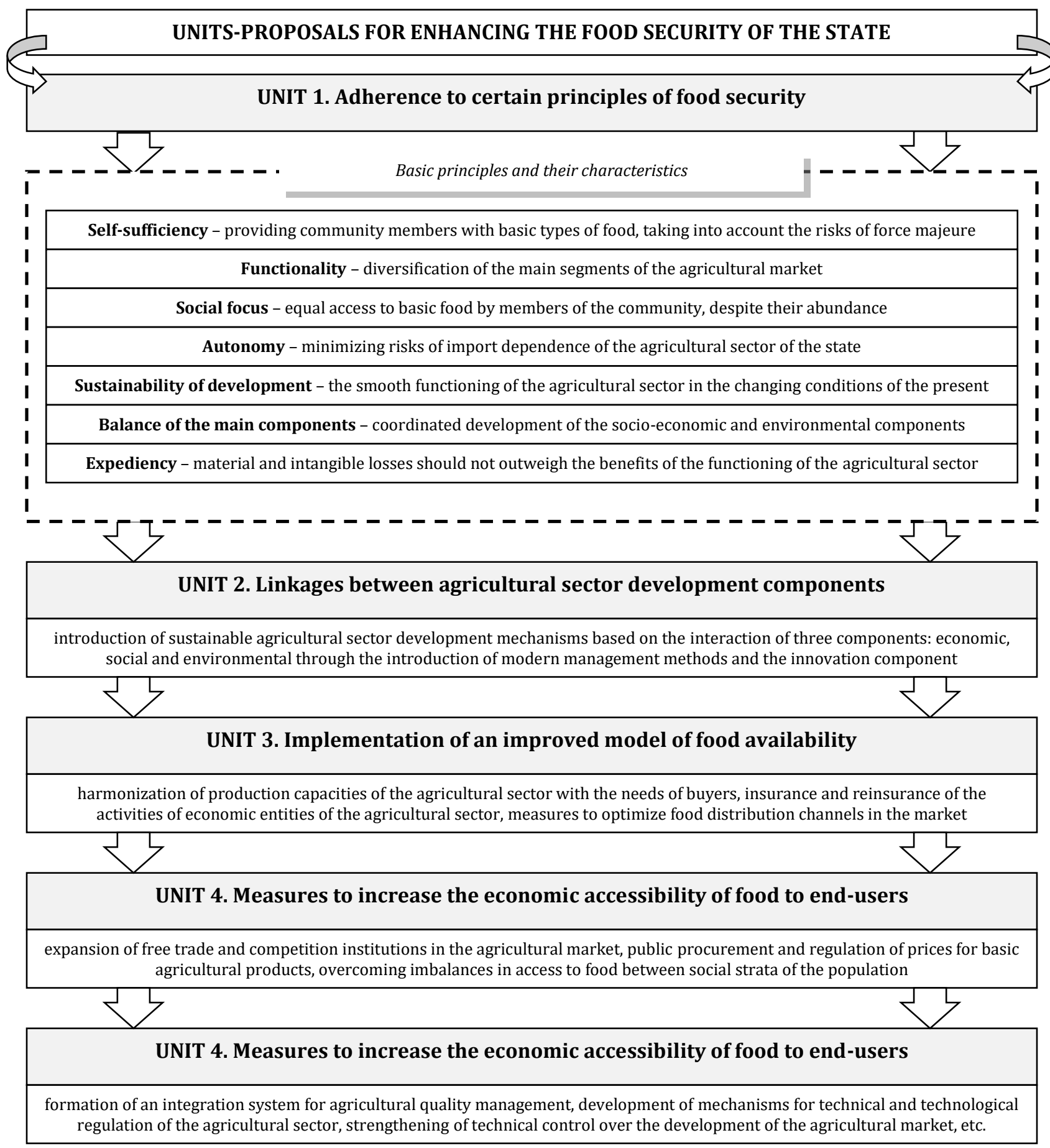

Figure 3. Description of block proposals for strengthening the food security of the state.

Source: author's development based on Bianco (2016); Brockwell and Davis (2016); Riabokon (2016).

So, if sufficient funds are allocated for interesting and 5. The strengthening of the competitive position of the ambitious investment-innovation projects, this will help agricultural sector of Ukraine to attract external attract talented young specialists to solve problems and investment is a direct result of the effective and improve their skills in the agricultural sector.

4. Agro-industrial complex modernization - consists in successful implementation of a collection of investmentinnovative projects. successful implementation of previous proposals and is the main driving force of the progress of the entire agricultural sector of Ukraine.

III. Optimization of agricultural sector financial support. 
The sustainable development of the economic security of the state and the meeting of the socio-economic needs of members of society largely depends on the competitive development of the agricultural sector of the Ukrainian economy. Its effectiveness largely depends on the level of its financial support, the key systemic role in the formation of which belongs to organizational and economic levers and instruments. A large number of issues related to the financing of the agricultural sector require justification of the financial strategy and its expeditious implementation, selection, and development of effective forms and new approaches to improving this mechanism. The following areas of improvement have been identified:

1. State support for agrarian production - is carried out to strengthen the general security of the state by providing targeted and non-targeted financial injections into various areas of the agrarian sector.

2 Commercial lending - is a competitive type of financial security and can be used both to introduce innovations and to maintain the existing system of production and sale.

3. Investment support - is the driving force for qualitative changes in the agrarian sphere and strengthening the state's economic security system.

4. Development of the system of cooperative banks - is the key to the reliability of the banking system of the state and an effective tool for financial support of the agricultural sector.

5. Alternative sources consist of agricultural receipts, bill avalization, forward contracts, and warehouse warrants, which is a proven option in the international practice of sustainable financial support for the development of the agricultural sector of the state economy.

Thus, it can be concluded that research, justification, updating, introduction, and monitoring of the implementation of these proposals to improve the mechanisms for the development of the agricultural sector of the economy will achieve significant results in strengthening the general system of economic security of the state in the long term.

\section{CONCLUSIONS}

There were conducted research on the formation and improvement of mechanisms to ensure the development of the agricultural sector in the state's economic security system in the article. The following theoretical- methodical and practically applied results and generalizations were obtained:

Approaches to the definition of the category "economic security of the state" are summarized and a clarified definition is provided, namely, the ability of the state to develop and perform effectively political, socioeconomic and other functions in a constantly changing external and internal environment, that is, the state of protection of important interests of the state from internal and external destabilizing factors (challenges, threats, risks and hazards) to ensure the sustainability of the development of national security by improving the functioning of strategically important sectors and branches of the economy, preventing external economic aggression and the possibility of progression in the future.

It has been proved that the agrarian sector can both form the resource basis for the socio-economic development of the state, while ensuring its food security, and create the prerequisites for the development of the agro-industrial complex by increasing economic efficiency and export potential, as well as creating reliable security for the development of agricultural territories of various purposes with existing or potential possible infrastructure. A common mechanism for ensuring the development of the agricultural sector in the system of economic security of the state has been created, the functioning of which, in turn, directly depends on internal and external destabilizing factors and will be based on the improvement of three interconnected mechanisms: strengthening the food security of the state; increasing investment attractiveness by introducing an innovative component; optimization of agricultural sector financial support.

\section{REFERENCES}

Avanesova, N. E., O. S. Mordovtsev and Y. I. Serhiienko. 2020. The Theoretical-Methodical Principles of Identification and Interrelation of the Influence of Destabilizing Factors on the Economic Security of an Industrial Enterprise. Business Inform, 9: 2028.

Bianco, A. 2016. Green Jobs and Policy Measures for a Sustainable Agriculture. Agriculture and Agricultural Science Procedia, 8: 346-352.

Boiko, V. 2017. Diversification of business activity in rural areas as a risk minimization tool of economic 
security. Management Theory and Studies for Rural Business and Infrastructure Development, 39: 19-32.

Brockwell, P. J. and R. A. Davis. 2016. Forecasting Techniques. Introduction to Time Series and Forecasting. Springer International Publishing, p. 309-321.

Gevorgyan, A., O. Drugova and S. Klepikova. 2018. Factors influencing the determination of investment attractiveness and business value. Visnyk Nacionaljnogho tekhnichnogho universytetu «Kharkivsjkyj politekhnichnyj instytut, 19: 131-134.

Honcharenko, S. I. 2017. Innovative resource-saving technologies as a factor in improving the efficiency of agricultural production. Bulletin of Kharkiv National Technical University of Agriculture: Economic Sciences, 185: 131-142.

Hryhorenko, Y. O. 2017. Scientific and methodological principles of comprehensive assessment of the agricultural potential of regional relations of Ukraine under the condition of ensuring economic security. Agrosvit, 11: 70-76.

Hunchak, N. V., T. H. Vasyltsiv and O. Y. Sukhai. 2016. State management of the process of intellectualization of Ukraine's economy. Apriori, Lviv.

Kruhlov, V. V. and D. A. Tereshchenko. 2019. PublicPrivate Partnership as Tool for Developing Regional Labor Potential. Science and innovation, 15: 5-13.

Lelechenko, A., O. Lebedinska, S. Somin, V. Vakulenko and N. Pikh. 2020. Introduction of the Concept of Sustainable Development in the Context of the Constitutional Reform of Ukraine. Journal of the National Academy of Legal Sciences of Ukraine, 27: 53-65.

Nepomnyashchyy, O. M., O. A. Marusheva, Y. H. Prav, O. V. Medvedchuk and I. A. Lahunova. 2020. Certain Aspects of the System of Public Administration of Universities: World Practices and the Ukrainian
Dimension. Universal Journal of Educational Research, 8: 82-86.

Orlova, N. S., O. A. Diegtiar, O. V. Kozureva, A. M. Shapovalova and S. I. Prykazka. 2019. Financial capacity of territorial communities: European experience and Ukrainian case. Financial and credit activity: problems of theory and practice, 4 : 516-526.

Popova, O. L. 2016. Rural development as a component of modern agricultural policy. Scientific Bulletin of the National University of Life and Environmental Sciences of Ukraine. , 247: 254-64. Series: Economics, Agricultural Management, 247: 254264.

Riabokon, V. P. 2016. Agro-industrial complex in the conditions of realization of the state agrarian policy. 9: 18-26. Economy APK, 9: 18-26.

Romanenko, Y. 2016. Place and role of communication in public policy. , 176(2): 25-31. Actual Problems of Economics, 176: 25-31.

Shevchenko, I. Y., O. M. Nepomnyashchyy, O. A. Marusheva, O. V. Medvedchuk and I. A. Lahunova. 2020. Marketing communications management in the public administration system. , 9: 2882-90. International Journal of Criminology and Sociology, 9: 2882-2890.

Stetsiuk, P. A. 2016. Modernization of the mechanism of financial support of agricultural production. Accounting and Finance, 1.

Urba, S. I. 2017. The mechanism of ensuring the development of food security of Ukraine: theoretical aspect. Bulletin of Lviv National University. Economic Series, 54: 325-331.

Urba, S. I. 2019. The agricultural sector in the system of economic security of Ukraine: Problems of theory and practice. Ivan Franko Lviv National University, Lviv.

Zinchuk, T. 0. 2017. The modern paradigm of the Common Agrarian Policy YES as a counteraction to the global challenge and disintegration. , 10: 7885. Economics APK, 10: 78-85. 
Publisher's note: EScience Press remains neutral with regard to jurisdictional claims in published maps and institutional affiliations.

(c)

Open Access This article is licensed under a Creative Commons Attribution 4.0 International License, which permits use, sharing, adaptation, distribution and reproduction in any medium or format, as long as you give appropriate credit to the original author(s) and the source, provide a link to the Creative Commons license and indicate if changes were made. The images or other third-party material in this article are included in the article's Creative Commons license, unless indicated otherwise in a credit line to the material. If material is not included in the article's Creative Commons license and your intended use is not permitted by statutory regulation or exceeds the permitted use, you will need to obtain permission directly from the copyright holder. To view a copy of this license, visit http://creativecommons.org/licenses/by/4.0/. 